Available online:

http://journal.imla.or.id/index.php/arabi

IMLA

Arabi : Journal of Arabic Studies, 5 (2), 2020, 142-152

DOI: http://dx.doi.org/10.24865/ajas.v5i2.293

\title{
ARABIC LANGUAGE DIRECTIVE SPEECH ACT IN SALAHUDDIN AL-AYYUBI MOVIE
}

\author{
Nailur Rahmawati, Retno Purnama Irawati, Muchlisin Nawawi, Sulimah \\ Universitas Negeri Semarang, Indonesia \\ E-mail : nailur_rahma99@mail.unnes.ac.id
}

\begin{abstract}
A movie can be used as an effective and feasible medium for delivering messages; this served as the study's rationale. This research acquired communicative speeches in the Salahuddin Al Ayyubi movie. This research aimed to explore two objectives: to describe the form of directive speech acts and to find out the functions of the directive speech acts. The techniques used in this research comprised: (1) uninvolved conversation observation; (2) recording; (3) transcription; and (4) note-taking. The results showed that (1) there were six forms of directive speech acts in the dialogues of "Saladin al-Ayyubi", i.e., imperative, request, invitation, advice, criticism, and prohibition; (2) the functions of directive speech acts in the dialogues of "Saladin alAyyubi" are quite varied. The imperative functions had 83 speech data. The request function comprised 52 speech data. The invitation function involved 33 speech data. The advice function consisted of 39 speech data. The criticism act had 13 speech data. The prohibition function consisted of 23 speech data.
\end{abstract}

Keywords: speech acts, directive, Arabic movie

\begin{abstract}
Abstrak
Film dapat dijadikan sebagai media penyampaian pesan yang efektif dan layak untuk dikaji lebih jauh pada kajian tindak tutur. Dalam penelitian ini, peneliti mengambil tuturan yang terjadi pada komunikasi di dalam film Salahuddin al-Ayyubi. Penelitian ini mempunyai dua tujuan, yaitu untuk mendeskripsikan bentuk tindak tutur direktif dan fungsi tindak tutur direktif. Teknik penelitian meliputi empat tahapan, yaitu: (1) Teknik simak bebas libat cakap; (2) teknik merekam; (3) teknik transkripsi; (4) teknik catat. Hasil penelitian menunjukkan (1) bentuk tindak tutur direktif dalam dialog film "Shalahuddin al-Ayyubï" terbagi menjadi enam, yaitu perintah, permintaan, ajakan, nasihat, kritikan, dan larangan, (2) Fungsi tindak tutur direktif dalam dialog film "Shalahuddin al-Ayyubi" cukup bervariasi. Fungsi perintah berjumlah 83 data tuturan. Fungsi permintaan berjumlah 52 data tuturan. Fungsi ajakan berjumlah 33 data tuturan. Fungsi nasihat berjumlah 39 data tuturan. Fungsi kritikan berjumlah 13 data tuturan. Fungsi larangan berjumlah 23 data tuturan.
\end{abstract}

Kata Kunci: tindak tutur, direktif, bahasa Arab, film 


\section{Introduction}

Communication does not merely function as the medium of language transfer through words; it acts as the vessel of a speaker's act as well, or in linguistics, is referred to as speech act. Being regarded as one of the language functions, speech act carries a speaker's intention (Baktir, 2012). Chaer sees it as one's psychological utterance that contains the meaning of action (Chaer, 2010).

It is commonly accepted in linguistics that language possesses three components: syntactic, phonology, and semantics. Syntactic components of language are related to words, phrases, and sentences. Phonological components of language, in contrast, are related to sound as verbal signs of the human being to express what one intends (Setiyadi, 2009). Meanwhile, semantic components of language are central to the notion of meaning. A word possesses not only literal meaning as in the dictionary, but also certain meaning given by the users (semantic features of language) (Bagha, 2011).

On the other hand, pragmatics does not include a language component. Rather, it functions to provide perspectives in language, different when compared to semantics that disregards context and studies meaning in its purest form. Pragmatics refers to the study of meaning within the interaction between a speaker and an interlocutor. A communication is considered successful if mutual understanding between the speaker with the interlocutor occurs; or, in simpler words, the interlocutor can understand what the speaker intends to say (Awwad, 2017). This is in line with Leech (Wijaya \& Rohmadi, 2010), who exclaims that context plays a significant role in determining the meaning of an utterance within an interaction. Therefore, pragmatics intends to study meaning that is related to a given context; it scrutinizes the speaker's intention in trying to understand the interlocutor's intention.

Yule asserts that from the interlocutor's point of view, language features a directive function, i.e. a speech act expressed by a speaker to order someone to perform something (Yule, 2006). Language acts further than just influencing someone to perform a particular action, and it also directs which action to perform as the speaker intends. Prayitno divides speech acts into six categories: imperative, request, advice, invitation, critique, and prohibition (Prayitno, 2011).

The following is a sample of directive speech act:

A husband tells his wife: أنا جوعان جدا

The utterance "ana jau'anu jiddan" (Eng: "I am very hungry") is the declarative sentence that has istirham (pleading) trait; a husband pleads to his wife to prepare meals for him because he is very hungry (Tatang \& Syihabuddin, 2014).

The above sample indicates that context is one of the key aspects of an utterance. Context functions as the basis of consideration in describing the meaning of an utterance in a conversation; the absence of context makes it hard to identify the meaning and the objective of an utterance. The above example, as an utterance, does not only occur in literary works or movies, but also in daily life (Baktir, 2012).

Being regarded as the portrait of social life, movie contains certain scenes and communication topics; it also functions as an effective medium of message delivery and communicative interaction as well. The communication process involves speech acts delivered by the actors expressed in the form of conversations.

Movie, according to the KBBI Indonesian Dictionary, is a story of alive images with scenes, place settings, and given topics. The aforementioned elements are essential as the parts of speech context that aid one in understanding the meaning of a speech. Therefore, a movie is considered one of the media for linguists to study speech acts deeply.

This research highlights previous relevant studies focusing on directive speech act and pragmatics. Ayup Purnawan, in his study "Directive speech in Al-Quran: Pragmatic study of legal verses", elaborated that the directive speech of legal verses comprises direct and indirect directive speech acts. Moreover, regarding its function, he classifies the directive speech in legal verses into: 1) commanding, 2) prohibiting, 3) requiring, 4) forbidding, 5) permitting, and 7) giving 


\section{Arabi : Journal of Arabic Studies}

instructions. Despite the relevance, the study conducted by Ayup differs with the present study in terms of the focused research subject (Purnawan, 2009)(Amin, Safa, Darwis, \& Maknun, 2017).

Another study conducted by Tatang \& Syihabuddin entitled "Analysis of Directive Speech and Cultural Values in al- 'Arabiyah Bayna Yadayka Book" revealed the use of directive speech in the book. The directive speech data comprised question (93 data), invitation (eight data), request (nine data), offer (nine data), rejection (two data), and prohibition (one data). Both studies are different in the analyzed topic and research subject, in which Tatang \& Syihabuddin focused on directive speech and cultural values in the book, while the present study emphasizes on the directive speech in a movie (Tatang \& Syihabuddin, 2014).

Rachmat Budi Santosa in his research "Directive Speech Act in Story Verses in Al-Quran" discovers that only one verse contains requestive speech act. Moreover, the study generates nine data in question sub-directive, 60 data in requirement sub-directive, 19 data in prohibitive subdirective, two data in permissive sub-directive, and two data in advisory sub-directive. Both studies have different research subjects, in which Santosa focuses on Al-Quran story verses, meanwhile, this present study highlights movie dialog as the research subject (Santosa, 2017).

The previous section has displayed some relevant studies regarding directive speech act. This study, however, seeks to investigate such a topic in different subjects. It explains the process of directive speech act in movie dialog in which the speaker says something to instigate the interlocutor to perform an action.

This study focuses on analyzing speech acts in Salahuddin Al-Ayyubi movie. This study views the importance of conducting a pragmatic study of the Arabic language as one of the widely-learned languages in almost all education levels in Indonesia. On that ground, this study aims to elaborate directive speech acts in the Arabic movie of Salahuddin Al-Ayyubi. In particular, the study aims to analyze the types and functions of directive speech act in the movie. The data involved utterances or conversations conducted by the characters in the movie.

\section{Method}

A qualitative descriptive method was employed to analyze the verbal data containing types and functions of directive speech acts in Salahuddin Al-Ayubi movie as the data source. In addition, the data were analyzed by an identity method, i.e. a method that compares between intralingual or extralingual elements (Pranowo, 2015)(Noor \& Prayitno, 2016). The analysis, in particular, involved extralingual identity method and techniques as follows: 1) uninvolved conversation observation, 2) data record, 3) data transcription, and 4) note-taking. Extralingual method was conducted by comparing elements outside the language, i.e., the speech contexts (place and situation setting). The researcher was treated as the research instrument (or human instrument approach); data card was used to record the results of listening process of the movie dialog. The data were then validated with scrutinized observation and theory triangulation.

\section{Result}

The study focuses on the Salahuddin Al-Ayyubi movie from the first to fifth episode. The movie tells about a child named Salahuddin Al-Ayyubi in wonder of his own life decision; he decided his own fate without any intervention from his parents, but still seeking for his parents' approval. Each episode tells different topics. This research generates a classification table of types and functions of directive speech acts in Salahuddin Al-Ayyubi movie, as follows.

Table 1. Types and functions of directive speech act in "Salahuddin al-Ayyubi" movie

\begin{tabular}{cccccc}
\hline No. & Type & Data & Function & Data & Data example \\
\hline 1 & Imperative & 83 & Commanding & 25 & Tell to this young man about our opinion \\
\hline
\end{tabular}


Arabi : Journal of Arabic Studies

\begin{tabular}{|c|c|c|c|c|c|}
\hline No. & Type & Data & Function & Data & Data example \\
\hline & & & Ordering & 19 & أجل دعني وشأني \\
\hline & & & & & Yes, leave it. This is my business! \\
\hline & & & Giving instruction & 12 & | انتظري! \\
\hline & & & & & Wait \\
\hline & & & Requiring & 4 & توقفوا جميعكم \\
\hline & & & & & Stop, you all! \\
\hline & & & Forcing & 14 & توقفي .... عودي إلى هنا \\
\hline & & & & & Stop! Come back here! \\
\hline & & & Permitting & 9 & خذ \\
\hline & & & & & Take it \\
\hline \multirow{8}{*}{2} & \multirow{8}{*}{ Request } & \multirow{8}{*}{52} & Requesting & 21 & امهلني لحظة أفكر في الأمر \\
\hline & & & & & Give me some time to think about this matter \\
\hline & & & Expecting & 6 & 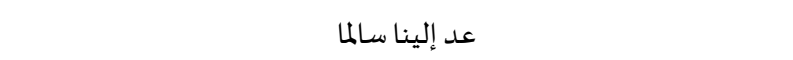 \\
\hline & & & & & Please come back to us safely \\
\hline & & & Asking & 12 & 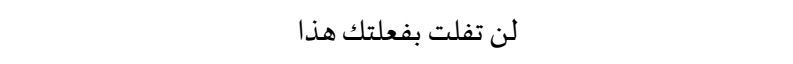 \\
\hline & & & & & You cannot do this \\
\hline & & & Offering & 13 & و المأكل والمسكن \\
\hline & & & & & Food and shelter \\
\hline \multirow{10}{*}{3} & \multirow{10}{*}{ Invitation } & \multirow{10}{*}{33} & Inviting & 21 & لتعد إلى البيت فورا \\
\hline & & & & & Come back home right away \\
\hline & & & Persuading & 1 & ألم تسمع شرف المهنة \\
\hline & & & & & Don't you know how important this task is? \\
\hline & & & Urging & 6 & 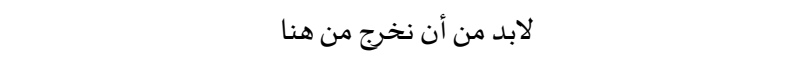 \\
\hline & & & & & We must get out of this place \\
\hline & & & Demanding & 1 & فليعملوا أكثر \\
\hline & & & & & Work diligently! \\
\hline & & & Challenging & 4 & كلام شجاع نظرا إلى أن سيفي معي \\
\hline & & & & & What a brave words! Look at the sword in my hana \\
\hline \multirow{10}{*}{4} & \multirow{10}{*}{ Advice } & \multirow{10}{*}{39} & Giving advice & 6 & إنم بخوات صغيرة \\
\hline & & & & & Walk with small steps \\
\hline & & & Suggesting & 4 & ل لم لانعطي رجنالد ما يريده \\
\hline & & & & & Why don't we just give what Riznaldi wants? \\
\hline & & & Pleading & 6 & 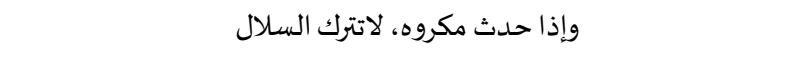 \\
\hline & & & & & If an accident occurs, don't leave that basket \\
\hline & & & Proclaiming & 10 & تعملون في المنجم حسبة أوامري \\
\hline & & & & & You, workers in this mine, follow my orders \\
\hline & & & Reminding & 13 & 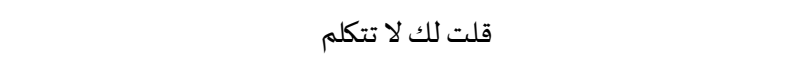 \\
\hline & & & & & Don't talk, I said! \\
\hline \multirow{4}{*}{5} & \multirow{4}{*}{ Criticism } & \multirow{4}{*}{13} & Insinuating & 1 & أهكذا تشكرني؟ \\
\hline & & & & & So this is how you thank me? \\
\hline & & & Criticizing & 1 & مظهرك محرج بما يكفي \\
\hline & & & & & You already look shameful enough \\
\hline
\end{tabular}




\begin{tabular}{|c|c|c|c|c|c|}
\hline No. & Type & Data & Function & Data & Data example \\
\hline & & & Threatening & 8 & سوف اقتلك حتى الموت \\
\hline & & & & & I will kill you! \\
\hline & & & Scolding & 3 & قلت لك ألا تخطأ أيها الثرثار \\
\hline & & & & & I told you, do not make mistakes, liar. \\
\hline \multirow{4}{*}{6} & & & Forbidding & 17 & لا لا تضئ نورا هنا \\
\hline & Prohibition & 23 & & & Do not use the light of the lamp there \\
\hline & & & Preventing & 6 & أتجثوا على الأرض \\
\hline & & & & & Kneel down! \\
\hline
\end{tabular}

This study discovered six forms of directive speech acts in the movie, i.e. imperative (83 utterances), request (52 utterances), invitation (33 utterances), advice (39 utterances), criticism (13 utterances), and prohibition (23 utterances). Additionally, the functions of directive speech act in the movie are described as follows:

1) Imperative act: ordering (19 data), commanding (25 data), instructing (12 data), requiring (four data), forcing (14 data), and permitting (nine data).

2) Request: requesting (21 data), expecting (six data), asking (12 data), and offering (13 data).

3) Invitation: inviting (21 data), persuading (one data), urging (six data), demanding (one data), and challenging (four data).

4) Advice: giving advice (six data), suggesting (four data), pleading (six data), proclaiming (ten data), and reminding (13 data).

5) Criticism: insinuating (one data), criticizing (one data), threatening (eight data), and scolding (three data).

6) Prohibition: forbidding (17 data), and preventing (six data).

\section{Discussion}

\section{Types of Directive Speech Acts in the Movie}

The following section is the discussion of six forms of directive speech acts in the Salahuddin al-Ayyubi movie.

a) Imperative

The following is a sample utterance of imperative speech act (data code SA/I/4/01:07)

$$
\text { توقفي .... عودي إلى هنا }
$$

Context: the speech is uttered by a fat male merchant to a little girl who was trying to flee. The speech is uttered in a high tone to force the little girl to return the bread she stole from him.

Based on the context, the data falls into an imperative act with the "forcing" function.

b) Request

The following is a sample utterance of request speech act (data code: $\mathrm{SA} / \mathrm{I} / 3 / 01: 00$ ).

$$
\text { اتركني! }
$$

Context: the speech is uttered by a little girl to the fat merchant with an expression of fear, begging to the fat merchant to let her hands free.

Based on the context, the data falls into a request act with the "asking" function.

\section{c) Invitation}

The following is a sample utterance of the invitation act (data code SA/I/6/01:39).

Context: The speech is uttered by SA to a little girl. He did not know that the girl has stolen something from a merchant, intending to ask the girl to flee from the male merchant.

Based on the context, the data falls into an invitation act with the "inviting" function. 


\section{d) Advice}

The following is a sample utterance of advice act (data code SA/I/8/03:42).

$$
\text { يا اهل الشام، انتهيوا الفرنجة يقتربون }
$$

Context: the speech is uttered by a messenger soldier in assertive, loud, and haste manner to warn the citizens from incoming attacks by the Europeans.

Based on the context, the data falls into an advice act with the "proclaiming" function.

e) Criticism

The following is a sample utterance of the criticism act (data code $\mathrm{SA} / \mathrm{I} / 15 / 08: 20$ ).

$$
\text { والآن عد إلى البيت قبل أشكوك لأبيك }
$$

Context: the speech is uttered by SA to a little child with an intimidating tone, threatening the child to tell his father if he would not return the old man's cane.

Based on the context, the data falls into a criticism act with a "threatening" function.

\section{f) Prohibition}

The following is a sample utterance of the prohibition act (data code SA/I/14/08:18).

$$
\text { حيلة الناكرة يا صغير }
$$

Context: the speech is uttered by grown-up SA to a little child who stole an old man's cane after the old man finished telling a story from the past. SA prevents the child from leaving with the old man's cane by holding the cane and forbid the child not to repeat his misconduct.

Based on the context, the data falls into a prohibition act with the "forbidding" function.

\section{Functions of Directive Speech Act in the Movie}

The functions of the directive speech act in the movie are elaborated as follows:

\section{a. Functions of Imperative Act}

The imperative speech act is a type of speech that is performative, creating certain obligations for the speaker or speech recipient. Explicit performative speech can be a promise or command to do the same for both speakers and recipients (Condoravdi \& Lauer, 2012)(Amin et al., 2017). The imperative act in the movie comprises functions as follows: ordering, commanding, giving instruction, requiring, forcing, and permitting. Each function is elaborated in the following section:

\section{1) Ordering}

The 'ordering' function comprises 19 data. The following is a sample utterance of the 'ordering' act (data code: SA/I/5/01:24).

$$
\text { أجل دعني وشأني }
$$

Context: The speech is uttered by a little girl to SA with an expression of disapproval, implying that the girl ordered SA not to interfere with her business.

2) Commanding

The 'commanding' function comprises 25 data. The following is a sample data of 'commanding' act (data code: $\mathrm{SA} / \mathrm{I} / 22 / 13: 29$ ).

$$
\text { أخبر الفتى برأينا }
$$

Context: The speech is uttered by $M$ to Dr, implying that $M$ rejected T's offers and commanded Dr to expel $\mathrm{T}$ from their place.

\section{3) Forcing}

The 'forcing' function comprises 14 data. The following data $\mathrm{SA} / \mathrm{I} / 4 / 01: 07$ is a sample utterance of the 'forcing' act.

$$
\text { توقفي .... عودي إلى هنا }
$$

Context: The speech is uttered by a fat male merchant to a girl trying to run away. The merchant forced the girl to return the bread she stole from him. 


\section{Arabi : Journal of Arabic Studies}

\section{4) Permitting}

The 'permitting' act contains nine data. The following data $\mathrm{SA} / \mathrm{I} / 54 / 23: 36$ is a sample utterance of the 'permitting' act.

Context: The speech is uttered by SA's father as he handed out the family heritage sword to SA.

5) Requiring

The 'requiring' function has four data. The following data SA/II/9/02:17 is a sample utterance of 'requiring' act.

$$
\text { توقفوا جميعكم }
$$

Context: The speech is uttered by SA loudly asking the group to calm down.

6) Giving instruction

The 'giving instruction' act has 12 data. The following data SA/V/1/00:18 is a sample utterance of 'giving instruction' act.

$$
\text { ها هو }
$$

Context: The speech is uttered by SA to instruct $\mathrm{T}$ of the direction to which the chased man was running.

\section{b. Functions of Request Act}

The request act in the movie comprises functions as follows: requesting, expecting, asking, and offering. Each function is elaborated in the following section:

\section{1) Requesting}

The 'requesting' act consists of 21 data. The following is a sample utterance of the 'requesting' act (data code: $\mathrm{SA} / \mathrm{I} / 17 / 12: 05)$.

$$
\text { السلطان يحتاج إليك هنا والناس يحتاج إليك هنا }
$$

Context: The speech is uttered by SA's father when he saw SA looking at the family heritage sword. SA's father requested him to cancel his plan to cooperate with Musthofa to fight for the nation against the European invaders.

\section{2) Expecting}

The 'expecting' act contains six data. The following data $\mathrm{SA} / \mathrm{I} / 10 / 05: 01$ is a sample of the 'expecting' act.

$$
\text { هذا السيف كان سيف والدي لسنوات طويلة. لم يجلب له العارمطلقا. وأنا سأكمل بهذه المسيرة }
$$

Context: The speech is uttered by S's father and SA while handing the sword to S, expecting that $\mathrm{S}$ would be able to live up to the history of the legacy sword.

\section{3) Asking}

The 'asking' act comprises 12 data. The following data $\mathrm{SA} / \mathrm{I} / 3 / 01: 00$ is a sample of the 'asking' act.

$$
\text { اتركني! }
$$

Context: the speech is uttered by a little girl to the fat merchant with an expression of fear, begging to the fat merchant to let her hands free.

4) Offering

The 'offering' act contains 13 data. The following data $\mathrm{SA} / \mathrm{I} / 1 / 00: 48$ is a sample utterance of the 'offering' act.

$$
\text { طاري ولذيذ خبزا هذا الصبباح }
$$

Context: the speech is uttered by a fat bread seller in the market in offering his bread to the visitors. 


\section{c. Functions of Invitation Act}

The invitation act in the movie comprises functions as follows: inviting, persuading, urging, demanding, and challenging. Each function is elaborated in the following section:

\section{1) Inviting}

The 'inviting' act comprises 21 data. The following data $\mathrm{SA} / \mathrm{I} / 6 / 01: 39$ is a sample utterance of the 'inviting' act.

Context: the speech is uttered by SA to a little girl he did not know has stolen something from a merchant, intending to ask the girl to flee from the merchant.

2) Persuading

The 'persuading' act contains only one data (code: SA/I/44/18:21)

$$
\text { ألم تسمع شرف المهنة }
$$

Context: the speech is uttered by A to persuade Dr of the importance of the duty A was performing; A persuaded Dr to let oneself free and give the pearl to A.

3) Urging

The 'urging' act consists of six data. The following data SA/I/13/05:58 is a sample of the 'urging' act.

$$
\text { لا أريد أن أموت }
$$

Context: the speech is uttered by T to urge SA to come back home while they were within the ruins of a building.

4) Demanding

The 'demanding' act only contains one data (code: SA/V/11/05:06)

$$
\text { فليعملوا أكثر }
$$

Context: the speech is uttered by Dr to demand the subordinate who brought small pieces of silver ore to work harder to bring more.

5) Challenging

The 'challenging' act comprises four data. The following data SA/II/24/05:08 is an example of the 'challenging' act.

$$
\text { كلام شجاع نظرا إلى أن سيفي معي }
$$

Context: the speech is uttered by SA to challenge the bandit leader by pointing the sword against his neck after the bandit leader said that SA would not be able to escape with one of the bandit members' horses.

\section{d. Functions of Advice Act}

The advice act in the movie involves functions as follows: giving advice, suggesting, pleading, proclaiming, and reminding. Each function is elaborated in the following section:

1) Giving advice

The 'giving advice' function six data. The following data SA/II/37/10:22 is a sample of 'giving advice' act

$$
\text { أجل دروس القائد ترداد شراسة في كل مرة }
$$

Context: the speech is uttered by a fat subordinate of B to advise SA to not fight against $\mathrm{B}$, as $\mathrm{B}$ is known as a cruel king.

2) Suggesting

The 'suggesting' function involves four data. The following data SA/II/41/10:53 is a sample of 'suggesting' act

$$
\text { لا تخجل مما حدث، الكل يخضيع في النهاية }
$$

Context: the speech is uttered by Dn to suggest SA to stop fighting B and admit his defeat, because everyone $\mathrm{N}$ had caught would ultimately surrender. 


\section{Arabi : Journal of Arabic Studies}

\section{3) Pleading}

The 'pleading' act involves six data. The following data SA/IV/6/01:43 is a sample utterance of the 'pleading' act.

$$
\text { تذكر العدو لن يصد ما لا يمكنه توقع }
$$

Context: the speech is uttered by Zh while countering SA's attacks. Zh pleads to SA not to be complacent about SA's win against him and to keep practicing.

\section{4) Proclaiming}

The 'proclaiming' act involves ten data. The following data SA/IV/16/04:41 is an example of 'proclaiming' act

$$
\text { أعظم مصارع قتال في حلبة }
$$

Context: the speech is uttered by B's subordinate to inform the citizens of an upcoming show that would feature a strong wrestler $(Z)$.

\section{5) Reminding}

The 'reminding' act contains 13 data. The data SA/IV/28/17:10 is a sample utterance of the 'reminding' act.

$$
\text { لا تفعل هذا يا زهير! }
$$

Context: the speech is uttered by SA to remind $\mathrm{Zh}$ of their plans after he discovered that $\mathrm{Zh}$ broke the promise and tried to attack SA.

\section{e. Functions of Criticism Act}

The criticism act in the movie involves functions as follows: insinuating, criticizing, threatening, and scolding. Each function is elaborated in the following section:

1) Insinuating

The 'insinuating' act involves only one data (data code: SA/I/53/22:11)

$$
\text { أهكذا تشكرني؟ }
$$

Context: the speech is uttered by A to sarcastically insinuated SA of his misconduct. SA helped A get out of the fire but instead tried to steal the Persian pearl A took away from Dr.

\section{2) Criticizing}

The 'criticizing' act only contains one data (data code: SA/II/35/09:16)

$$
\text { مظهرك محرج بما يكفي }
$$

Context: the speech is uttered by SA to bash B after B argued that SA had embarrassed B. SA instead criticized that B was more shameful than him.

\section{3) Threatening}

The 'threatening' act involves eight data. The following data $\mathrm{SA} / \mathrm{I} / 15 / 08: 20$ is a sample utterance of the 'threatening' act.

$$
\text { والآن عد إلى البيت قبل أشكوك لأبيك }
$$

Context: the speech is uttered by SA to a little child with an intimidating tone, threatening the child to tell his father if he would not return the old man's cane.

\section{4) Scolding}

The 'scolding' act contains three data. The following is a sample utterance of the 'scolding' act(data code: SA/I/18/12:12).

$$
\text { كيف تجرأ، أخوك كان بطلا }
$$

Context: the speech is uttered by SA's father to SA with a very high tone after SA refused his father's request and shifted the conversation by re-asking the story of his older sibling. 


\section{f. Functions of Prohibition Act}

The prohibition act in the movie involves functions i.e., forbidding and preventing. Each function is elaborated as follows:

\section{1) Forbidding}

The 'forbidding' act comprises 17 data. The following data SA/I/14/08:18 is a sample of the 'forbidding' act.

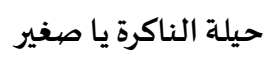

Context: the speech is uttered by grown-up SA to a little child who stole an old man's cane after the old man finished telling a story from the past. SA prevents the child from leaving with the old man's cane by holding the cane and forbid the child not to repeat his misconduct.

\section{2) Preventing}

The 'preventing' act contains six data. The following data $\mathrm{SA} / \mathrm{I} / 2 / 00: 58$ is a sample utterance of 'preventing' act.

$$
\text { يا لها من يد رقيقة }
$$

Context: the speech is uttered by a fat male bread seller to stop a little girl from stealing his bread. The bread seller caught the little girl's hand to prevent her from taking away the bread.

\section{Conclusion}

Based on the analysis, it is found that there are six forms of directive speech acts in Salahuddin al-Ayyubi movie, including imperative, request, invitation, advice, criticism, and prohibition. The functions of directive speechacts in the dialogues of "Salahuddin al-Ayyubi" movie are quite varied where there were 83 imperative speeches, 52 request speeches, 33 invitation speeches, 39 advice speeches, 13 criticism speeches; and 23 prohibition speeches.

The result also indicates that this research is implicative towards the readers, including the researchers and linguistic students, in variation of directive speech acts. The information regarding the directive speech act used in the movie can serve as the reference in interaction and communication. The result of directive speech act in the movie instigates various potential research focuses for further studies on different linguistics problems, such as language variation, interference, and deixis. Hence, the present study is expected to be the reference for Arabic language learners regarding the implementation of a pragmatic field of study on a daily basis, particularly in an Arabic conversation.[]

\section{References}

Amin, N., Safa, H. N. H. A., Darwis, H. M., \& Maknun, T. 2017. "Pragmatics Analysis: Arabic Directive Imperative Speech Acts Used in Alquran", International Journal of Science and Research (IJSR), Vol. 6, No. 1.

Awwad, M. 2017. "Linguistic Meaning Versus Pragmatic Meaning”, European Scientific Journal, Vol. 13, No. 26.

Bagha, K. N. 2011. “A Short Introduction to Semantics”, Journal of Language Teaching and Research, Vol. 2, No. 6.

Baktir, H. 2012. "Speech Act Theory: Austin, Searl Derrida's Response and Deleuze's Theory of Order-word", Language, Literature and Cultural Studies, Vol. 5, No. 2.

Chaer, A. 2010. Kesantunan Berbahasa. Jakarta: Rineka Cipta.

Condoravdi, C., \& Lauer, S. 2012. "Imperatives: Meaning and Illocutionary Force", Empirical Issues in Syntax and Semantics, Vol. 9. 
Arabi : Journal of Arabic Studies

Noor, K. U., \& Prayitno, H. J. 2016. "Pergeseran Kesantunan Positif Siswa Kelas IX MTs N 1 Surakarta Berlatar Belakang Budaya Jawa", Kajian Linguistik Dan Sastra, Vol. 1, No. 1.

Pranowo, P. 2015. "Unsur Intralingual dan Ekstralingual Sebagai Penanda Daya Bahasa dan Nilai Rasa Bahasa dalam Kesantunan Berkomunikasi”, Adabiyyat: Jurnal Bahasa Dan Sastra, Vol. 14, No. 2.

Prayitno, H. J. 2011. Kesantunan Sosiopragmatik. Surakarta: Universitas Muhammadiyah Press.

Purnawan, A. 2009. "Tuturan Direktif dalam Alquran: Kajian Pragmatik terhadap Ayat-Ayat Hukum", Thesis, Universitas Gadjah Mada.

Santosa, R. B. 2017. "Tindak Tutur Direktif pada 'Ayat-Ayat Kisah' dalam Alquran”, Disertasi, Surakarta Sebelas Maret University.

Setiyadi, A. C. 2009. "Bahasa dan Berbahasa Perspektif Psikolinguistik", At-Ta'dib, Vol. 4, No. 2.

Tatang \& Syihabuddin. 2014. "Analisis Tuturan Direktif dan Nilai Budaya Pada Buku al'Arabiyah Bayna Yadayka", El Harakah Jurnal Budaya Islam, Vol. 16, No. 1.

Wijaya, I. D. P., \& Rohmadi, M. 2010. Analisis Wacana Pragmatik: Kajian Teori dan Analisis. Surakarta: Yuma Pustaka.

Yule, G. 2006. Pragmatik Penerjemah. Yogyakarta: Pustaka Pelajar. 